\title{
Histopathological Study of Epithelial, Melanocytic And Adnexal Tumors Of Skin- A Retrospective Study In A Tertiary Care Centre
}

\author{
Sandhya Pitla* and Vijayasri Dara \\ Department of Pathology, Pinnamaneni Siddhartha Institute of Medical Sciences and Research Foundation. India
}

\begin{abstract}
Background and Objectives: To classify and identify various skin tumors and study their variations according to age and sex. The most common predisposing factors being fair skin, sun exposure, chemical exposure, HPV infection in the setting of immunosuppression.

Methods: This was an observational study carried out in the Department of Pathology at private Medical College of coastal Andhra from July 2018 to June 2020.

Result: The present study included histopathological study of 71 cases of tumors of skin and its adnexae over a period of two years. Out of the 71 tumors, 43 were diagnosed as benign and 28 as malignant tumors of skin constituting $61 \%$ and $39 \%$ respectively. The ratio of benign to malignant tumors was 1:0.63. Among the 43 benign tumors $20(46.5 \%)$ were tumors of skin appendages, $15(34.9 \%)$ were tumors of epidermis, $8(18.6 \%)$ were of melanocytic origin. Among the 28 malignant tumors $25(89.3 \%)$ were tumors of epidermis, $2(7.1 \%)$ were melanocytic tumors and $1(3.6 \%)$ was tumor of skin appendages. Among the malignant epidermal tumors squamous cell carcinoma was the most common constituting $42.9 \%$ (12 cases).

Conclusion: The present study concludes that benign tumors are most common when compared to malignant tumors of skin. Among the malignant tumors, Squamous cell carcinoma falls as the most common variety of skin followed by Basal cell carcinoma and verrucous carcinoma. Among the benign tumors, tumors of epidermal origin are most frequent followed by tumors of sweat gland and adnexal-hair follicle origin.
\end{abstract}

\section{Keywords: Keratinocytic tumors, Melanocytic tumors, Hidradenoma, Spiradenoma, Basal cell Carcinoma (BCC),} Squamous Cell Carcinoma (SCC)

\section{Introduction}

The skin or integument is a complex organ with many functions and with three main anatomic components: epidermis and skin adnexae, melanocytic system, and dermis and subcutis ${ }^{[1]}$. The skin is a heterogenous organ with varied elements having ectodermal and mesodermal origins. Most of the individual elements are capable of producing skin tumors ${ }^{[2]}$. Based on their primary site of origin, they can be divided in to the following: i) Keratinocytic tumors ii) Melanocytic tumors iii) Appendageal tumors iv) Soft tissue tumors.

Of all the diagnosed cancers in India, less than $1 \%$ of tumors are of skin cancers. Worldwide BCC is the commonest cutaneous malignancy, but in India SCC is reported to be the most prevalent skin cancer ${ }^{[3]}$. There has been an alarming increase of skin cancer among fair skinned populations. Differences in trends and rates of skin cancer may be due to variation in skin types, geographical latitudes, occupational exposure, behavior in terms of sun exposure and skin protection and differences in disease awareness and surveillance ${ }^{[4]}$. Keratinocytic tumours account for approximately $90 \%$ or more of all skin malignancies, of which approximately $70 \%$ are basal cell carcinomas $^{[5]}$.

Appendageal tumours are neoplasms whose differentiation is towards one or more of the adnexal structures of the skin. Depending on their presumed origin, adnexal tumours are categorized into those with apocrine and eccrine, follicular and sebaceous differentiation ${ }^{[6]}$. Neoplasms with ductular differentiation often have debatable histogenesis ${ }^{[7]}$.

The study of adnexal neoplasms present unique difficulties in part related to the wide variety of tumors, the substantial frequency of one lesion exhibiting histological features of two or more adnexal lines and the complicated nomenclature ${ }^{[8]}$.

The study of skin tumors is interesting, more intriguing, fascinating and challenging because of its wide variations and there has been no systemic study being done earlier. Keeping in view these facts, an attempt is made to study the different varieties of tumors of skin which will bear impact on patient management and prognosis. The aid of histopathology is crucial in clinching the right diagnosis and in further management. The aims of the present study are to 
1. To find out the incidence of different epithelial, melanocytic and adnexal tumors of skin.

2. To classify and identify various skin tumors and study their variations according to age and sex.

3. To study the histopathology of different skin tumors.

\section{Materials and Methods}

All the biopsies, specimens and reference materials submitted to the Department of Pathology at private medical hospital of coastal Andhra for histopathological study during the period from July 2018 to June 2020. Tissue specimens received to the department of pathology was noted and fixed in 10\% formalin for 12-36 hours. Extent of sampling depended on the size of tumor as follows. This study got approved by institutional ethics committee.

Specimens measuring $3 \mathrm{~mm}$ or less were submitted in toto. Specimens measuring 4-6 mm were cut through the centre and both halves submitted for processing. Specimens measuring $7 \mathrm{~mm}$ or more, a $2-3 \mathrm{~mm}$ slice was cut through the centre and submitted for processing. Further tissue was processed and embedded in paraffin blocks. Sections of 3 to 5 microns thickness were taken and stained with hematoxylin and eosin and studied.

Inclusion criteria: Tumors of epidermis along with melanocytic tumors and tumors of skin appendages without restricting the study to a particular age limit.

Exclusion criteria: Mesenchymal tumors, hematological tumors, skin secondaries and non-neoplastic lesions are excluded from the study

Statistical methods applied: Data was analyzed using number and percentage of statistical methods in the present study.

\section{Result}

During the 3 years study from July 2018 to June 2020, there were 71 cases of tumors of skin. Out of the 71 cases, 28 cases are malignant and 43 cases are benign tumors of skin constituting $39 \%$ and $61 \%$ respectively. The ratio of malignant to benign tumors was 0.63:1 (Table 1)

In the present study the peak incidence of benign tumors of skin and its adnexae was between 4th and 5th decade with female preponderance. The peak incidence of malignant tumors of skin and its adnexae was in 6th decade with male preponderance. Out of 71 skin tumors, malignant epidermal tumors were most common (35.2\%), followed by benign tumors of appendages (28.2\%), benign tumors of epidermis $(21.1 \%)$, benign melanocytic tumors $(11.3 \%)$, malignant melanoma $(2.8 \%)$ and malignant adnexal tumor (1.4\%). Seborrheic keratosis comprises majority of cases among the benign tumors of skin and its adnexae constituting about 11 cases with a percentage of about $25.6 \%$ and with male preponderance followed by benign melanocytic nevi, and others. In this study, 6 cases of intradermal nevus were seen. Peak incidence was seen in 5 th decade. Histologically the dermis showed nests, cords and sheets of nevus cells showing maturation. Two cases of compound naevi were encountered in the present study and the age of the patients were 23 and 55 years respectively. Histologically epidermis was thinned out and showed junctional activity with dermal component of nevus cells showing maturation. (Table2)

In the present study among the malignant tumors of skin and its adnexae, Squamous cell carcinoma constitutes about $42.9 \%$ followed by basal cell carcinoma of $39.3 \%$, Malignant melanoma and verrucous carcinoma of $7.1 \%$ each and malignant adnexal tumor of $3.6 \%$

All squamous cell carcinoma were graded conventionally as well, moderate and poorly differentiated. Majority of squamous cell carcinomas were well differentiated (58.4\%) and the other two grades of squamous cell carcinomas constitute about $41.6 \%$. In the present study 11 cases of basal cell carcinoma were encountered and accounted for $39.3 \%$ of the malignant tumors of the skin. Basal cell carcinomas showing no differentiation were categorized as solid basal cell carcinoma. In the infiltrating variant of basal cell carcinoma, the basaloid cells were arranged in the form of cords and showed deep infiltration in the dermis. One case of Basosquamous carcinoma was found in which the basal cell carcinoma coexisted with squamous cell carcinoma and it was seen as an ulcer in a 45 years old male patient. Among the histological types of basal cell carcinoma, pigmented type was the most common constituting $45.4 \%$. Peak incidence was in 4th and 5th decade. Male to female ratio was 1.75:1. (Table 4).

In the present study 21 cases of skin adnexal tumors were encountered, out of which 20 were benign and 1 was malignant. In the present study benign tumors formed the majority (95.2\%). Among the benign tumors the occurrence of sweat gland tumors $(61.9 \%)$ was the highest followed by hair follicle tumors (33.3\%). Among the malignant tumors a single case of sweat gland carcinoma (4.8\%) was encountered. Malignant tumors of hair follicle differentiation and benign and malignant tumors of sebaceous differentiation were not encountered in the present study

\section{Discussion}

Skin malignancies are rare in India compared to western countries. In India skin malignancies constitute about $1-2 \%$ of all diagnosed cancers. Keratinocytic tumours are 
Table 1: Distribution and incidence of benign and malignant tumors of skin.

\begin{tabular}{|l|l|l|l|}
\hline & $\begin{array}{l}\text { Number of } \\
\text { Epidermal Tumors }\end{array}$ & $\begin{array}{l}\text { Number of } \\
\text { Adnexal Tumors }\end{array}$ & $\begin{array}{l}\text { Number of } \\
\text { Melanocytic Tumors }\end{array}$ \\
\hline Benign & $15(21.1 \%)$ & $20(28.2 \%)$ & $8(11.3 \%)$ \\
\hline Malignant & $25(35.2 \%)$ & $1(1.4 \%)$ & $2(2.8 \%)$ \\
\hline Total & $\mathbf{4 0}$ & $\mathbf{2 1}$ & 10 \\
\hline
\end{tabular}

Table 2: Incidence of various benign tumors of skin and its adnexae.

\begin{tabular}{|c|c|c|}
\hline Tumors & Number of Cases & Percentage (\%) \\
\hline \multicolumn{3}{|l|}{ Epidermal tumors } \\
\hline Seborrheic keratosis & 11 & 25.6 \\
\hline Verruca vulgaris & 03 & 7.0 \\
\hline Keratoacanthoma & 01 & 2.3 \\
\hline \multicolumn{3}{|c|}{ Adnexal - Hair follicle tumors } \\
\hline Pilomatricoma & 06 & 14 \\
\hline Trichoepithelioma & 01 & 2.3 \\
\hline \multicolumn{3}{|l|}{ Sweat gland tumors } \\
\hline Hidradenoma & 07 & 16.3 \\
\hline Cylindroma & 04 & 9.3 \\
\hline Spiradenoma & 02 & 4.6 \\
\hline \multicolumn{3}{|l|}{ Melanocytic tumors } \\
\hline Melanocytic naevi & 08 & 18.6 \\
\hline
\end{tabular}

Table 3: Incidence of malignant tumors of skin and its adnexae.

\begin{tabular}{|l|l|l|}
\hline Type of Malignant tumor & Number of Cases & Percentage \\
\hline Squamous cell carcinoma & 12 & 42.9 \\
\hline Verrucous carcinoma & 2 & 7.1 \\
\hline Basal cell carcinoma & 11 & 39.3 \\
\hline Malignant melanoma & 2 & 7.1 \\
\hline Malignant adnexal tumor & 1 & 3.6 \\
\hline
\end{tabular}

Table 4: Histological types of basal cell carcinoma.

\begin{tabular}{|l|l|l|}
\hline Histological Type & Number of cases & Percentage \\
\hline Pigmented & 05 & 45.4 \\
\hline Solid & 02 & 18.2 \\
\hline Adenoid & 01 & 9.1 \\
\hline Infiltrating & 02 & 18.2 \\
\hline Baso-squamous & 01 & 9.1 \\
\hline
\end{tabular}

Table 5: Incidence of skin adnexal tumors .

\begin{tabular}{|l|l|l|l|}
\hline Type of the Tumor & Number of Benign tumors & $\begin{array}{l}\text { Number of Malignant } \\
\text { tumors }\end{array}$ & Total \\
\hline Hair follicle differentiation & $7(33.3 \%)$ & - & $7(33.3 \%)$ \\
\hline Sweat gland differentiation & $13(61.9 \%)$ & $1(4.8 \%)$ & $14(66.7 \%)$ \\
\hline Sebaceous differentiation & - & - & \\
\hline Total & $\mathbf{2 0}(\mathbf{9 5 . 2} \%)$ & $\mathbf{1 ( 4 . 8 \% )}$ & $\mathbf{2 1}$ \\
\hline
\end{tabular}




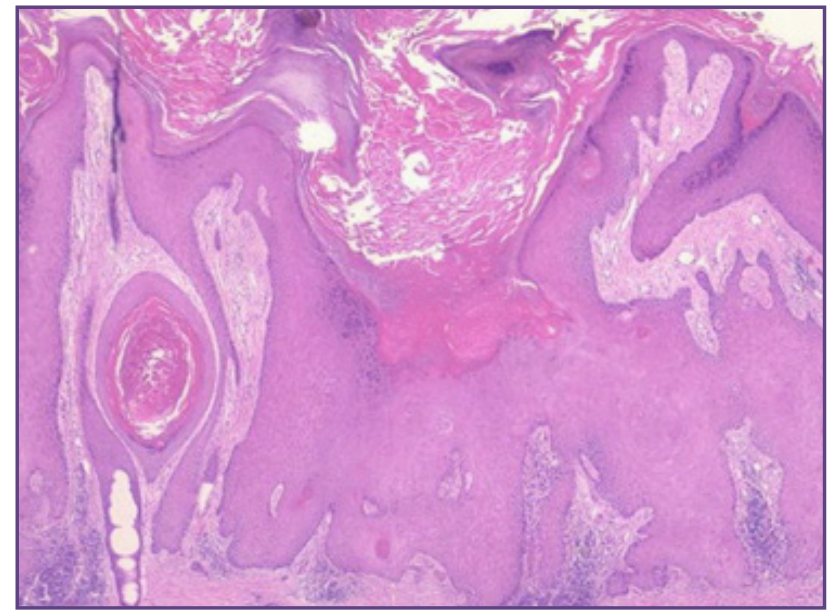

Fig. 1: Keratoacanthoma Photomicrograph showing central crater surrounded by keratinocytes. (H\&E x 100).

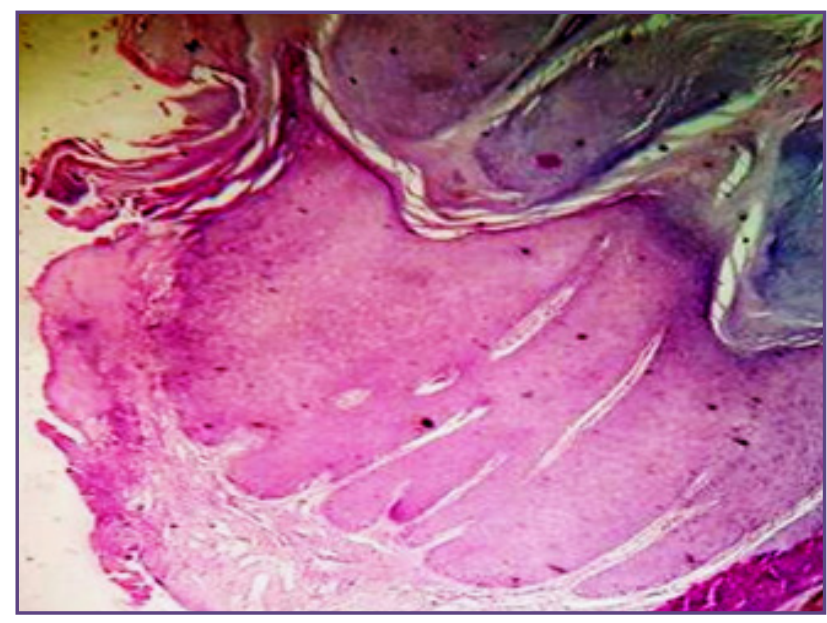

Fig. 3: Verruca vulgaris Photomicrograph showing acanthosis, hyperkeratosis and papillomatosis (H\&Ex 100).

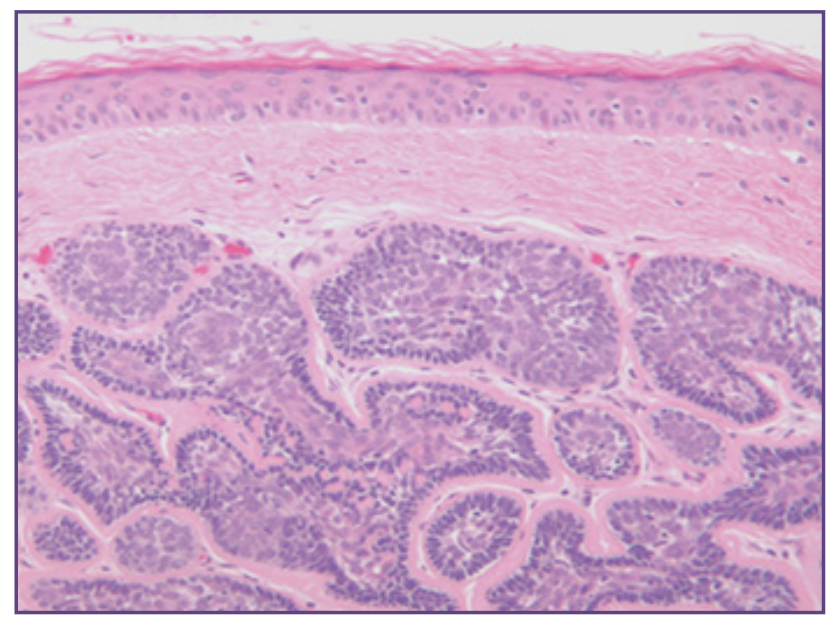

Fig. 5 : Cylindroma Photomicrograph showing jigsaw puzzle like arrangement of tumor cells. (H\&E x100).

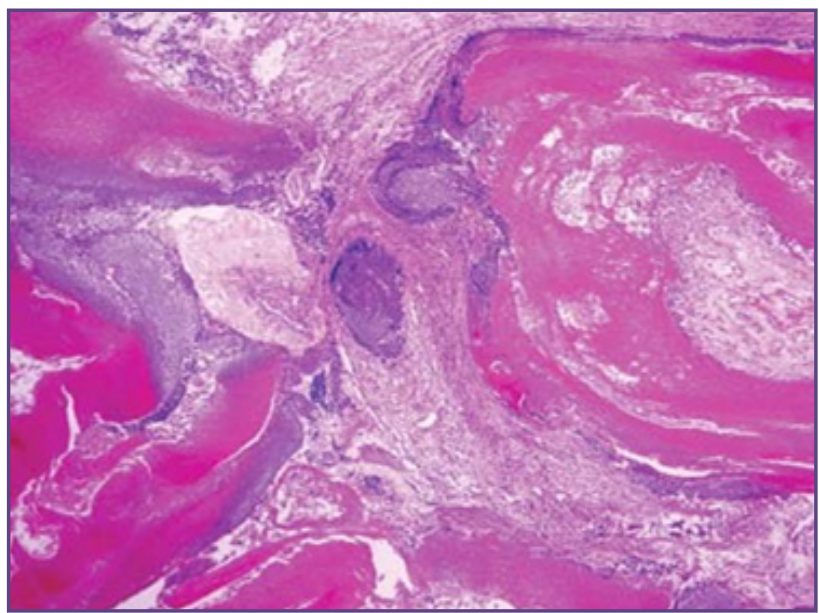

Fig. 2: Pilomatricoma Photomicrograph showing basaloid cells and eosinophilic keratin material (H\&E x100).

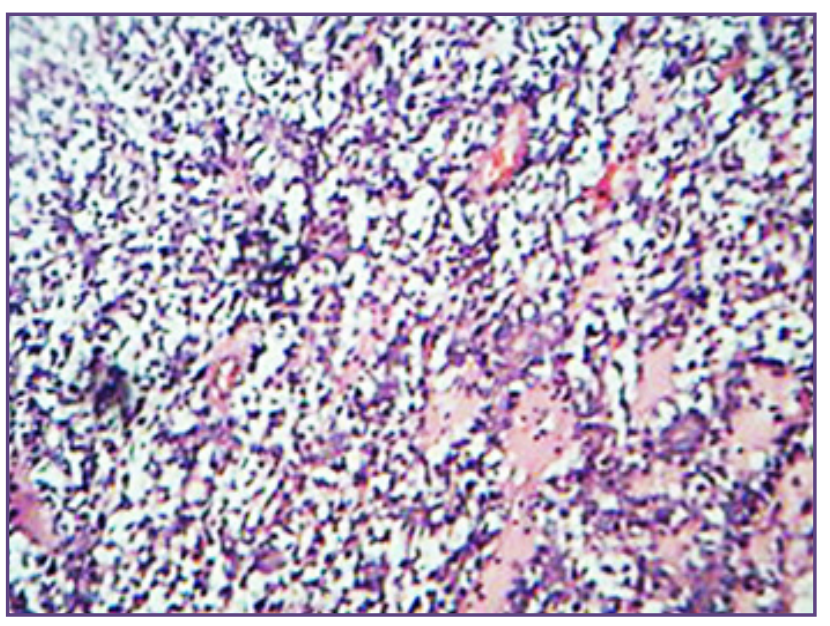

Fig. 4: Clear cell hidradenoma Photomicrograph showing Hidradenoma with tumor cells containing clear cytoplasm. (H\&E X400)

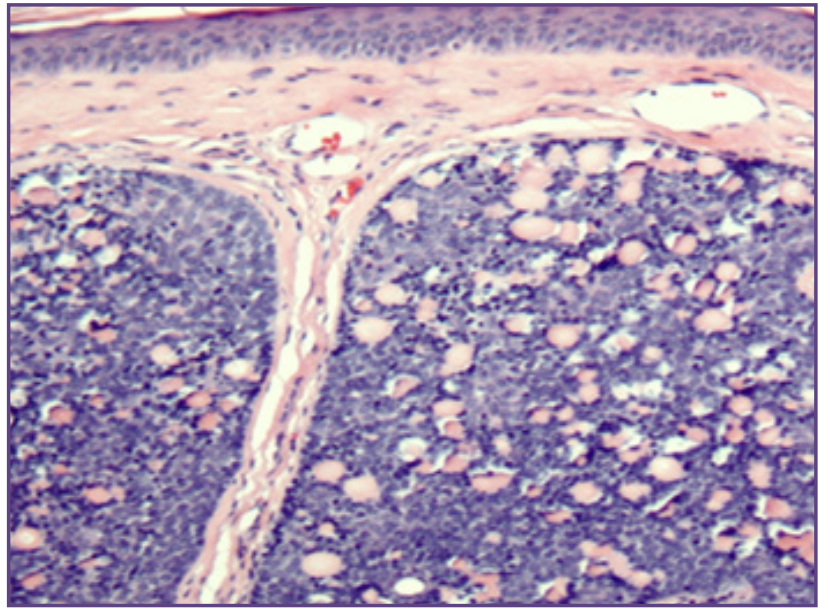

Fig. 6: Spiradenoma Photomicrograph showing nodules of basaloid cells in the dermis. (H\&E x100. 


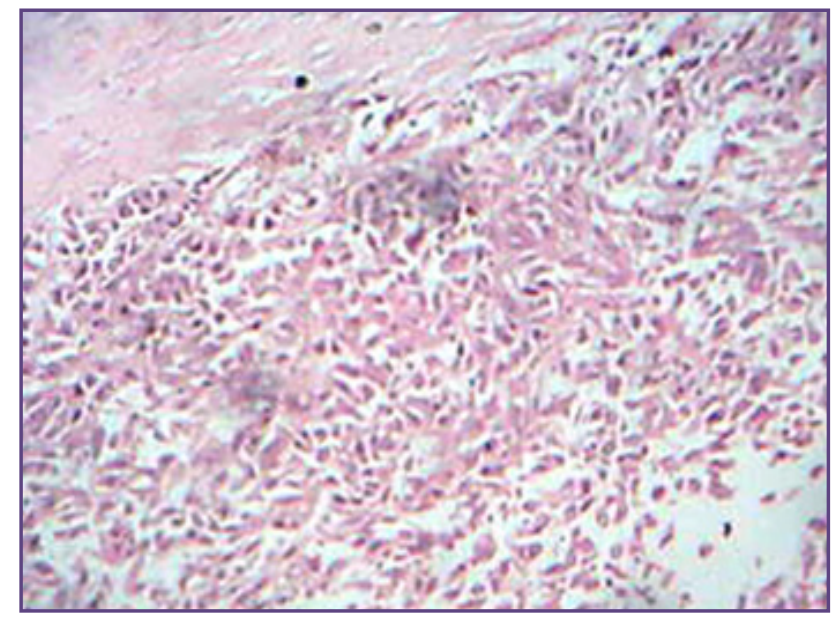

Fig. 7: Malignant melanoma Photomicrograph showing sheets of pleomorphic tumor cells (H\&E x100).

derived from epidermal and adnexal keratinocytes and comprise a large spectrum of lesions ranging from benign proliferations (acanthomas) to malignant squamous cell carcinomas which occasionally show aggressive growth and even metastatic potential. Keratinocytic tumours are very frequent and, despite their low mortality rate, pose a significant public health problem. The main etiologic factor is solar radiation ${ }^{[9]}$.

All the tumors arising from mucocutaneous junctions (including tumors around eyelids, anterior nares, mouth, corona gland is penis, vulval orifice and the anal orifice, dermal tumors and secondaries were excluded from the study. Among the 71 skin tumors 43 were benign tumors and 28 were malignant tumors of skin and its adnexae. The ratio of benign (43) to malignant tumors (28) was 1:0.63. The ratio of benign epidermal tumors (15) to malignant counterparts (25) was $0.6: 1$. The ratio of benign adnexal tumors (20) to malignant adnexal tumors (1) was 20:1. The ratio of benign melanocytic tumors (8) to malignant counterpart (2) was $4: 1$. Out of 71 skin tumors, malignant epidermal tumors were most common $(35.2 \%)$, followed by benign adnexal tumors $(28.2 \%)$, benign tumors of epidermis (21.1\%), benign melanocytic tumours $(11.3 \%)$, malignant melanoma $(2.8 \%)$ and malignant adnexal tumor (1.4\%).

In the present study squamous cell carcinoma accounted for maximum number of cases $(42.9 \%)$ which is similar to the observations made by Deo SV et al ${ }^{[10]}$, Chakravorthy RC and Choudhuri DR ${ }^{[11]}$ and Bhudaraja SN et al ${ }^{[12]}$ ( Table 6)

Table 6: Comparative incidence of different malignant tumors of skin in India.

\begin{tabular}{|l|l|l|l|l|}
\hline Type of the Tumor & Deo SV et al ${ }^{[10]}$ & $\begin{array}{l}\text { Chakravorthy and } \\
\text { Choudhuri }{ }^{[11]}\end{array}$ & Bhudaraja et al ${ }^{[12]}$ & Present Study \\
\hline Squamous cell carcinoma & $55.8 \%$ & $72.21 \%$ & $50.34 \%$ & $42.9 \%$ \\
\hline Verrucous carcinoma & - & - & - & $7.1 \%$ \\
\hline Basal cell carcinoma & $18.1 \%$ & $16.5 \%$ & $17.65 \%$ & $39.3 \%$ \\
\hline Malignant melanoma & $26.1 \%$ & $8.69 \%$ & $29.41 \%$ & $7.1 \%$ \\
\hline Adnexal carcinoma & - & $2.6 \%$ & $2.6 \%$ & $3.6 \%$ \\
\hline
\end{tabular}

Table 7: Comparison of incidence of benign adnexal tumors.

\begin{tabular}{|l|l|l|l|l|}
\hline Type of the tumor & Solanki et al ${ }^{[13]}$ & Nair ${ }^{[14]}$ & Reddy et al[15] & Present Study \\
\hline Hair follicle tumors & $22(23.4 \%)$ & $12(36.36 \%)$ & $13(22 \%)$ & $7(35 \%)$ \\
\hline Sweat gland tumors & $50(53.2 \%)$ & $19(57.58 \%)$ & $43(73 \%)$ & $13(65 \%)$ \\
\hline Sebaceous gland tumors & $22(23.4 \%)$ & $2(6.06 \%)$ & $3(5 \%)$ & - \\
\hline Total number of cases & $\mathbf{9 4}$ & $\mathbf{3 3}$ & $\mathbf{5 9}$ & $\mathbf{2 0}$ \\
\hline
\end{tabular}

Table 8: Comparison of histological types of basal cell carcinoma.

\begin{tabular}{|l|l|l|}
\hline Histological Type & Solanki RL et al ${ }^{12}$ & Present Study \\
\hline Pigmented & $6.4 \%$ & $45.4 \%$ \\
\hline Solid & $60.5 \%$ & $18.2 \%$ \\
\hline Adenoid & $15.7 \%$ & $9.1 \%$ \\
\hline Keratotic & $9.3 \%$ & - \\
\hline Infiltrating & $4.6 \%$ & $18.2 \%$ \\
\hline Basosquamous & $3.5 \%$ & 9.1 \\
\hline
\end{tabular}




\section{Malignant tumors of epidermis}

In the present study among the tumors of adnexal origin, benign tumors formed the majority $(95.2 \%)$. In the study by Reddy et $\mathrm{al}^{14}$ et al also benign tumors formed the majority(Table 7). The occurrence of sweat gland tumors (65\%) was higher in the present study which correlates with the studies done by Solanki et al ${ }^{[13]}$ (53.2\%), Nair $\operatorname{SP}^{[14]}(57.56 \%)$ and Reddy et $\mathrm{al}^{[15]}(73 \%)$.

6 cases of Pilomatricoma were noted in the present study accounting for $85.7 \%$ of the hair follicle tumors, with male to female ratio of 1:1 which correlates with the study by Solanki $\mathrm{RL}$ et $\mathrm{al}^{[13]}$. The mean age at presentation was 45 years in the present study where as it was 28 years in the study by Solanki RL et al ${ }^{[13]}$. Histologically the tumors were well circumscribed small to large-sized, cystic lesions lined focally by aggregations of basaloid cells and few squamoid cells and filled centrally with large masses of eosinophilic cornified material containing shadow (ghost) cells as well as a few keratin filaments.

One case of trichoepithelioma was encountered in the study accounting for $14.3 \%$ of the hair follicle tumors. The patient is female of age 47 years. Histologically, they showed islands of basaloid cells in the dermis with peripheral palisading of cells. Horn cysts and presence of fibrous stroma was noted. These observations were similar to those of Solanki RL et al ${ }^{[13]}$. 7 cases of Hidradenoma were encountered in the present study accounting for $53.8 \%$ of sweat gland tumors, with a male to female ratio of $0.75: 1$. In the study by Solanki RL et al ${ }^{[13]}$ hidradenoma accounted for $27.6 \%$ (13 cases) of sweat gland tumors with a male to female ratio of 1.16:1. 4 cases of cylindroma were noted in the present study accounting for $30.8 \%$ of sweat gland tumors of which 2 were males and 2 were females with male to female ratio of $1: 1$. Solanki RL et al ${ }^{[13]}$ observed all the 3 cases in males. 2 cases of Spiradenoma were noted in the present study accounting for $15.4 \%$ of sweat gland tumors of which one was male and the other one was female patient with male to female ratio of $1: 1$.

In the present study pigmented type of BCC was the most common type. In the study by Solanki RL et a ${ }^{[13]}$ solid BCC was the most common type(Table 8). Histologically the tumor showed lobules, columns, bands and cords of basaloid cells associated with scant cytoplasm and a characteristic outer palisade of cells associated with a surrounding loose fibromucinous stroma. Artefactual retraction spaces between the tumour and stroma were often present study.

\section{Conclusion:}

Skin tumors include tumors of epidermis, epidermal appendages and melanocytes. The diagnosis of skin tumors presents unique difficulties, in part, related to the wide variety of tumors and the complicated nomenclature. The present study concludes that benign tumors are most common when compared to malignant tumors of skin. Among the malignant tumors, Squamous cell carcinoma falls as the most common variety of skin followed by Basal cell carcinoma and verrucous carcinoma. Among the benign tumors, tumors of epidermal origin are most frequent followed by tumors of sweat gland and adnexalhair follicle origin. A diagnosis is a clinical tool that assists in the process of codifying patients into disease groups that tends to share a common outcome and a common set of responses to therapy. Thus, there is a close relationship between diagnosis and prognostication. Finally, the quintessence of the subject of study of skin tumors is its vastness, its enormity and its interesting histomorphology.

\section{Acknowledgements}

This article would not have been possible without the exceptional support of my teachers, colleagues, lab staff. The generosity and expertise of one and all have improved this study in innumerable ways and saved me from many errors: those that inevitably remain are entirely my own responsibility.

\section{Funding}

No funding

\section{Competing Interests}

No competing interests in the present study.

\section{Reference}

4. Montagna W, Kligman AM, Carlisle KS: Atlas of normal human skin. New York, Springer-Velag, 1992.

5. Gloster HM Jr., Neal k. Skin cancer in skin of color. Jam Acad Dermatol 2006:55:741-60

6. Koh D, Wang H, Lee J Chia KS, Lee HP and Goh CL. Basal cell carcinoma, squamous cell carcinoma and melanoma of the skin:analysis of the Singapore Cancer Registry data 1968-97.British journal of Dermatology;148:1161-1166.

7. Godbole VK TopraniHT, Shah HH. Skin cancer in saurashtra. Ind J Pathol Bacteriol.1968;11:183-89.

8. Leboit PE, Burg G, Weedon D and Sarasin A. Pathology and genetics of skin tumors. In world health organization classification of tumors. IARC press.Lyon, 2006.p.9-164.

9. Requena L, Kiryu H, Ackerman AB (1998). Neoplasms with apocrine differentiation. Lippincott Williams \& Wilkins: Philadelphia.

10. McCalmont TH (1996). A call for logic in the classification of adnexal neoplasms. Am J Dermatopathol 18: 103-109.

11. Klein W, Chan E and Seykora JT. Tumors of the epidermal appendages. In lever's histopathology of skin. 9th ed. Philadelphia: Lippincott raven;2005. p.867-926. 
12. Lober BA, Lober CW, Accola J (2000). Actinic keratosis is squamous cell carcinoma. J Am Acad Dermatol 43:881-882.

13. Deo SV, Hazarika Sidhartha, Shukla Nootan K, Kumar Sunil, Kar Madhabananda, Samaiya Atul Surgical management of skin cancers: Experience from a regional cancer centre in north india. Indian journal of cancer 2005.p.805-866.

14. Chakravorthy RC and Choudhuri DR. Malignant neoplasms of skin in Eastern india. The Indian journal off Cancer, vol 5.1968:133-144.

15. Bhudaraja SN, Pillai VCV, Periyanagam WJ, Kaushik SP and Bedi BMS. Malignant neoplasms of skin in Pondicherry- a study of 102 cases. The Indian journal of Cancer. 1972:284-295.

16. Solanki RL, Arora HL, Anand VK, GaurSK, Gupta R.Basal cell epithelioma( A clinicopathological study of 172 cases), Indian J Dermatology Venerology and leprology:1989 Vol 2 (55):33-43.

17. Nair SP. A clinicopathological study of skin appendageal tumors, Indian Journal of Dermatology, Venerology and Leprology 2008:74:108-550.

18. Reddy KM, Veliath AJ, Nagarajan S and Arora AL. A clinicopathological study of adnexal tumors of skin. Indian J Med Res 75, June 1982:882-889.

*Corresponding author:

Sandhya Pitla, Department of Pathology, Pinnamaneni Siddhartha Institute of Medical Sciences and Research Foundation. India. 520008

Phone: +91 9490845874

Email: sanju.pitla@gmail.com,

Date of Submission $\quad: \quad 17 / 07 / 2021$

Date of Final Revision : 13/08/2021

Financial or other Competing Interests: None.

Date of Acceptance $\quad: \quad 17 / 08 / 2021$

Date of Publication : $30 / 08 / 2021$ 